\title{
Kajian Hukum Pemberlakuan Perda Kota Medan Nomor 6 Tahun 2003 Perspektif Utilities Theory
}

\author{
Mhd. Yusrizal Adi Syaputra * \\ Universitas Medan Area \\ *Corresponding author: E-mail: yusrizal.adi@gmail.com
}

\begin{abstract}
Abstrak
Pemerintah Kota Medan memiliki kedudukan sebagai pemerintah daerah dan berperan penting dalam memberikan perlindungan kepada setiap masyarakat dan menjamin kesejahteraan sosial masyarakat setiap lapisan sosial dan ekonomi tanpa terkecuali. Peraturan Daerah Kota Medan Nomor 6 Tahun 2003 tentang Larangan Gelandangan dan Pengemisan serta Praktek Susila di Kota Medan tidak memberikan dampak positif dalam pengurangan masyarakat yang berprofesi sebagai pengemis, hanya sebagai landasan hukum bagi pemerintah Kota Medan dalam melakukan upaya Represfif pada masyarakat yang mengemis dijalanan sehingga pada Prinsipnya Peraturan Daerah tersebut belum mendatangkan manfaat bagi masyarakat yang termarjinalkan baik secara sosial maupun ekonomi.

Kata Kunci: Kesejahteraan Sosial, Pemerintah Kota Medan, Gelandangan, dan Pengemis, Peraturan Daerah

Abstract

The Medan City Government has a position as a regional government and plays an important role in providing protection to every society and ensures social welfare of every social and economic layer without exception. Local Regulation of Medan City Number 6 Year 2003 concerning Prohibition of Vagrant and Begging and Practice of Susila in Medan does not give a positive impact in the reduction of people who work as a beggar, only as legal basis for Medan City government in doing Repressive effort to people begging on the streets so that The principle of the Regional Regulation has not yet benefited the marginalized societies both socially and economically.
\end{abstract}

Keywords : Government, Vagrant, and Beggar, Local Regulation

How to Cite: Syaputra. M.Y.A., (2017), Kajian Hukum Pemberlakuan Perda Kota Medan Nomor 6 Tahun 2003 Perspektif Utilities Theory, Mercatoria, 10 (2): 197-215. 
Mhd. Yusrizal Adi Syaputra, Kajian Hukum Pemberlakuan Perda Kota Medan Nomor 6 Tahun 2003 Perspektif Utilities Theory

\section{PENDAHULUAN}

Fakta sejarah menunjukkan bahwa pembangunan bangsa Indonesia selalu terkait dengan upaya mengatasi kemiskinan, baik pembangunan pada masa orde lama, orde baru, maupun era Reformasi saat ini. Pada masa orde lama, kemiskinan yang dihadapi cenderung sangat gradual dan merata diseluruh tanah air, mengingat pada saat itu Indonesia baru saja terlepas dari cengkaraman penjajah. Sedangkan kemiskinan yang dihadapi Orde Baru lebih mencerminkan terjadinya ketidakmerataan hasil-hasil pembangunan sehingga menimbulkan jurang pemisah antara kaya dan miskin. ${ }^{1}$

Pasal 34 Undang-Undang Dasar Negara Republik Indonesia tahun 1945 menyatakan bahwa

(1) Fakir miskin dan anak-anak terlantar dipelihara oleh negara.

(2) Negara mengembangkan sistem jaminan sosial bagi seluruh rakyat dan memberdayakan masyarakat yang lemah dan tidak mampu sesuai dengan martabat kemanusiaan.

(3) Negara bertanggung jawab atas penyediaan fasilitas pelayanan kesehatan dan fasilitas pelayanan umum yang layak.

(4) Ketentuan lebih lanjut mengenai pelaksanaan pasal ini diatur dalam undang-undang.

Sebelum adanya amandemen Undang-Undang Dasar Negara Republik Indonesia tahun 1945 tahun 1999 s/d 2002, ketentuan Pasal 34 berbunyi bahwa

${ }^{1}$ Ambar Teguh Sulistiyani, Kemitraan dan Model-Model Pemberdayaan, Gava Media, Yogyakarta, 2017, hal.4
Fakir miskin dan anak-anak terlantar dipelihara oleh negara.

Yusril Ihza berpendapat bahwa

Pasal 34 UUD 1945 mengatakan

"Fakir miskin dan anak-anak yang terlantar dipelihara oleh negara". Pasal ini sebenarnya tidaklah berdiri sendiri, tetapi terkait erat dengan pasal $39 \mathrm{di}$ atasnya yang mengatur dasar "demokrasi ekonomi negara". Oleh karena itu, penjelasan atas pasal 34 mengatakan "telah jelas, lihat di atas". Artinya maksud yang dikandung pasal 34 itu "telah jelas" dikemukakan dalam penjelasan atas pasal 33. Memang, kedua pasal ini (pasal 33 dan 34) termasuk ke dalam bab yang sarna, yaitu Bab XIV yang judulnya "Kesejahteraan Sosial". Jadi, jika digunakan penafsiran sistematik, maka masalah "fakir miskin dan anak-anak yang terlantar" itu penyelesaiannya haruslah dikaitkan dengan asas "demokrasi ekonomi" yang dikandung oleh pasal sebelumnya. ${ }^{2}$

Kemiskinan secara eksplisit adalah sebagai fenomena yakni hanay akan dilihat bagaimana upaya masyarakat dalam memenuhi kebutuhan, dan sampai sejauhmana upaya tersebut mampu meraih apa yang diinginkan. Akan tetapi, pada prinsipnya kemiskinan bukan sekedar fenomena, tetapi lebih merupakan proses yang tereduksi akibat kerentanan yang melanda pada banyak faktor. Mengingat bahwa kemiskinan bukanlah

2 Yusril Ihza Mahendra Perlukah UndangUndang Tentang Perlindungan Fakir Miskin Dan Anak Terlantar?, Majalah Hukum dan Pembangunan, Nomor 3 Tahun XXV Juni 1995, hal.227 
sekedar fenomena, olehkarena itu tidak dapat dibenarkan jika program-program pengentasan kemiskinan hanya terfokus pada upaya bagaimana kemampuan masyarakat dalam memenuhi kebutuhan hidupnya. Sebagaiman telah disinggung dimaka, bahwa aras pemikiran ini terlalu dangkal dan tidak menyentuh masalah yang lebih mengakar pada inti persoalan yang sesungguhnya, tetapi ironisnya ini yang berkembang adalah aras pemikiran seperti itu. Tidak pelak lagi bahwa apa yang diharapkan dari program penanggulangan kemiskinan tidak akan mampu memecahkan masalah yang sebenarnya. Kemiskinan akan terentaskan jika program diarahkan untuk memberikan stimulasi bagi upaya pemberdayaan masyarakat. Dengan demikian, masyarakat akan melakukan proses menuju kemandirian yang sejati. ${ }^{3}$

Mengimplementasikan Pasal 34 Undang-Undang Dasar Negara Republik Indonesia tahun 1945 merupakan sebuah tanggungjawab Pemerintah. Melakukan perlindungan terhadap fakir miskin dan anak terlantar menjadi kewajiban bagi pemerintah.

Pelaksanaan ketentuan Pasal 34 tersebut diwujudkan dalam UndangUndang Nomor 11 Tahun 2009 Tentang Kesejahteraan Sosial. Di dalam penjelasan Undang-Undang Nomor 11 tahun 2009 dijelaskan bahwa Pembangunan kesejahteraan sosial merupakan perwujudan dari upaya mencapai tujuan bangsa yang diamanatkan dalam Undang-Undang Dasar Negara Republik Indonesia Tahun 1945. Sila kelima

${ }^{3}$ Ambar Teguh Sulistiyani, Op.cit. hal.4-5
Pancasila menyatakan bahwa keadilan sosial bagi seluruh rakyat Indonesia, dan Pembukaan Undang-Undang Dasar Negara Republik Indonesia Tahun 1945 mengamanatkan negara untuk melindungi segenap bangsa Indonesia dan seluruh tumpah darah Indonesia, memajukan kesejahteraan umum, mencerdaskan kehidupan bangsa, dan ikut melaksanakan ketertiban dunia berdasarkan kemerdekaan, perdamaian abadi, dan keadilan sosial. ${ }^{4}$

Permasalahan kesejahteraan sosial yang berkembang dewasa ini menunjukkan bahwa ada warga negara yang belum terpenuhi hak atas kebutuhan dasarnya secara layak karena belum memperoleh pelayanan sosial dari negara. Akibatnya, masih ada warga negara yang mengalami hambatan pelaksanaan fungsi sosial sehingga tidak dapat menjalani kehidupan secara layak dan bermartabat ${ }^{5}$.

Pada abad ke 20an berkembang keyakinan bahwa tata pemerintahan yang baik atau good governance adalah kunci untuk menjamin berlanjutnya perkembangan kehidupan. Dalam kehidupan yang bertambah kompleks, perubahan cepat, saling keterkaitan semakin tinggi, sumber daya alam semakin langka, kesenjangan semakin melebar dan ada kecenderungan daya dukung bumi semakin menurun, sehingga harus diatasi dengan tata pemerintahan yang baik yang bisa terwujud apabila semua komponen dan pihak dalam

4 Penjelasan Undang-Undang Noomr 11 tahun 2009 tentang Kesejahteraan Sosial

${ }^{5}$ Ibid. 
Mhd. Yusrizal Adi Syaputra, Kajian Hukum Pemberlakuan Perda Kota Medan Nomor 6 Tahun 2003 Perspektif Utilities Theory

kehidupan bersedia berperan serta atau berpartisipasi. ${ }^{6}$

Kota Medan sebagai salah satu Kota Metropolitan di Indonesia, hingga saat ini masih belum dapat memberikan akses perlindungan terhadap fakir miskin dan anak terlantar, malahan Pemerintah Kota Medan membuat sebuah peraturan Daerah yang pada prinsipnya bukan untuk melakukan perlindungan tetapi malahan menjadikan fakir miskin dan anak terlantar menjadi hal yang dilarang untuk ada di Kota Medan. Peraturan daerah kota medan Nomor : 6 Tahun 2003 Tentang Larangan Gelandangan Dan Pengemisan Serta Praktek Susila Di Kota Medan.

Di dalam konsiderans Menimbang Peraturan Daerah Nomor 6 tahun 2003 menyatakan diantaranya ${ }^{7}$ :

a. Bahwa salah satu upaya Pemerintah Kota Medan mewujudkan tercapainya Kota Medan menjadi Kota Bestari, perlu meningkatkan pelaksanaan penanggulangan gelandangan dan pengemis serta praktek tuna susila secara terpadu di Kota Medan

b. Bahwa dengan semakin meningkatnya dan perkembangan jumlah gelandangan dan pengemis serta praktek tuna susila, yang melakukan kegiatan pengemisan di medan-medan jalan, traffic light, pelataran masjid-masjid dan

6 Sedarmayanti, Good Governance (Kepemerintahan yang baik) dan Good Corporate Governance ( tata Kelola Perusahaan yang baik), CV. Mandar Madju, Bandung, 2007, hal.9

${ }^{7}$ Konsideran Menimbang Peraturan Daerah Kota Medan Nomor : 6 Tahun 2003 Tentang Larangan Gelandangan Dan Pengemisan Serta Praktek Susila Di Kota Medan. jembatan-jembatan penyebrangan serta kegiatan tuna susila ditempattempat umum, taman-taman, pinggiran sungai, bawah jembatan, hotel, losmen, dan tempat lainnya di kota medan.

c. Bahwa kegiatan yang dilakukan dengan berbagai cara, untuk menimbulkan belas kasihan orang lain, ini merupakan penyakit mental atau pemalas yang tidak sejalan dengan ajaran agama, sedangkan tuna susila merupakan tindakan yang bertentangan dengan normanorma sosial dan keagamaan dan sangat membahayakan kehidupan generasi muda serta dapat menyebabkan penyebaran virus AIDS / HIV dan virus penyakit lainnya yang semakin meluas.

d. Bahwa untuk maksud tersebut diatas perlu untuk menerbitkan satu ketentuan tentang larangan gelandangan dan pengemis serta praktek tuna susila di kota medan dan menetapkannya dalam satu Peraturan Daerah.

Peraturan daerah Kota Medan yang disahkan pada tahun 2003 tersebut menjadi sebuah polemik dalam penanganan dan perlindungan fakir miskin dan anak terlantar, jika dilihat dari perspektif sosial semata, fakir miskin dan anak terlantar menjadi hal yang dimasyarakat merupakan sebuah gejala, dalam perspektif ekonomi dapatlah dikatakan keadaan fakir miskin dan anak terlantar karena persaingan ekonomi. Hanya saja dalam kaca mata hukum, secara filosofi bahwa terjadinya probelmatika fakir miskin dan anak terlantar di tengah masyarakat 
merupakan sebuah akibat gagalnya pemerintah dalam mengelola pemerintahan. Hal tersebut dengan tegas dijabarkan dalam Pancasila sebagai philoshopie grundslag Negara Indonesia didalam sila kedua kemanusian yang adil beradab dan dalam sila ke lima yang menyatakan keadilan sosial bagi seluruh rakyat Indonesia.

Penegasan sila 2 dan sila 5 Pancasila diderivasikan kedalam Pasal 34 Undang-Undang Dasar Negara Republik Indonesia tahun 1945 dan di uraikan dalam Undang-Undang Nomor 11 tahun 2009 tentang Kesejahteraan Sosial. Pembentukan Undang-Undang Kesejahteraan Sosial pada dasarnya adalah untuk memberikan perlindungan kepada rakyat dan peningkatan kesejahteraan rakyat yang merupakan tujuan utama pembangunan negara Republik Indonesia.

Prinsip pokok pembangunan mengacu kepada kondisi rakyat yang hendak atau sedang dibangun. Kenyataan pertama yang harus dipegang adalah bahwa pembangunan yang diselenggarakan hari ini tidaklah hadir dalam ruang kosong (atau tidak ada ceteris paribusnya). Oleh karena, inti dari pembangunan pada dasarnya adalah penggerakan ekonomi rakyat. Ada pepatah mengatakan bahwa negara dalam kondisi berbahaya jika rakyatnya miskin. ${ }^{8}$

Konsep paradigma pembangunan (growt paradigm), merupakan arah pemikiran yang memperjuangkan terjadinya peningkatan pendapatan

8 Nugroho dalam Muammil Sun'an dan Abdurrahman Senuh, Ekonomi Pembangunan Daerah, Mitra Wacana Media, Jakarta, 2015, hal.17. masyarakat dan pendapatan negara, dengan demikian akan mampu mengejar ketertinggalan. Sasaran utama dari paradigma pertumbuhan ini adalah untuk menciptakan kondisi masyarakat dan negara lebih baik dengan mengusahakan adanya peningkatan pendapatan masyarakat dan pendapatan nasional sebagai komponen pembentuk pendapatan perkapita suatu negara. Peningkatan perkapita hendaknya secara bertahap dapat diraih sehingga akan memberikan kontribusi terhadap peningkatan kesejahteraan ekonomi ${ }^{9}$.

Peningkatan

kesejahteraan ekonomi masyarakat tidak dapat dipisahkan dari kesejahteraan sosial dari masyarakat sebuah daerah. Peran penting pemerintah daerah dalam meningkatkan kesejahteraan sosial dan ekonomi seperti yang diamanahkan oleh konstitusi Indonesia. Oleh karena itu, keberadaan Peraturan Daerah Kota Medan Nomor 6 Tahun 2003 Tentang Larangan Gelandangan Dan Pengemisan harus dilakukan pengkajian terhadap kedudukannya sebagai sebuah aturan yang menjadi landasan lahirnya kebijakan pemerintah daerah Kota Medan dalam mengatasi kemiskinan dan mengedepankan kesejahteraan sosialnya.

Berdasarkan latar belakang diatas, maka judul dalam penelitian ini adalah Kajian Hukum Pemberlakuan Perda Kota Medan Nomor 6 Tahun 2003 Perspektif Utilities Theory

\footnotetext{
${ }^{9}$ Ambar Teguh Sulistiyani, Op.cit, hal.43
} 
Mhd. Yusrizal Adi Syaputra, Kajian Hukum Pemberlakuan Perda Kota Medan Nomor 6 Tahun 2003 Perspektif Utilities Theory

\section{METODE PENELITIAN}

Menurut Hutchinson menempatkan penelitian hukum di dalam kategori Applied Research, dan membedakan penelitian hukum menjadi empat tipe, yakni10:

a) Doctrinal research; research which provides a systematic esposition of the rules governing a particular legal category, analyses the relationship between rules, explain areas of dificulty and, perhaps, predits future development.

b) Reform-Oriented Research: Research which intensively evaluates the adequacy of exiting rules and which recommends changes to any rules found wanting

c) Theretical Research: research which fosters a more complete understanding of the conceptual bases of legal principles and of combined effects of a range of rules and procedures that touch on a particular area of activity.

d) Fundamental research: Research designed to secure a deeper understanding of law as a social phenemonen, including research on the historical, philosophical, linguistic, economic, social or political implication.

Menurut Peter Mahmud Marzuki, bahwa penelitian hukum adalah suatu pross untuk menemukan aturan hukum, prinsip-prinsip hukum, maupun doktrindoktrin hukum guna menjawab isu hukum yang dihadapi. Berbeda dengan penelitian yang dilakukan di dalam keilmuan yang

10 Hutchinson dalam Peter Mahmud Marzuki, Penelitian Hukum, Kencana Prenada Media Group, Jakarta, Cet.5, 2009, hal.52 bersifat deskriptif yang menguji kebenaran ada tidaknya sesuatu fakta yang disebabkan oleh suatu fakto tertentu. Penelitian hukum dilakukan untuk menghasilkan argumentasi, teori dan konsep baru sebagai preskripsi dalam menyelesaikan masalah yang dihadapi. Jika pada keilmuan yang presktiptif jawaban yang diharapkan adalah true, appropriate, inappropriate atau wrong. Dengan demikian dapat dikatan bahwa hasil yang diperoleh di dalam penelitian hukum sudah mengandung nilai. ${ }^{11}$

1. Sumber Bahan Hukum

a. Sumber Bahan Hukum Primer Merupakan sumber bahan hukum yang utama yang berupa peraturan perundang-undangan yang berlaku.

b. Sumber Bahan Hukum Sekunder Merupakan sumber bahan hukum yang berupa, hasil penelitian, jurnal, bukubuku teks.

c. Sumber Bahan Hukum Tersier

Merupakan sumber bahan hukum sebagai pendukung yang berupa kamus, ensiklopedia, kamus Hukum dan internet.

Perkembangan teori hukum tidak terlepas dari keadaan lingkungan dan latar belakang permasalahan hukum atau menggugat suat pikiran hukum yang dominan pada saat itu. ${ }^{12}$

Teori atau pendapat dari Jeremy Bentham yang kemudian dikenal dengan filsafat Utilitarianisme. Menurut Bentham, benar salahnya tindakan harus dinilai

11 Ibid. Hal.35

12 Sacipto Rahardjo dalam Teguh Prasetyo dan Abdul Halim Barkatullah, Filsafat, Teori dan Ilmu Hukum : Pemikian Menuju Masyarakat Yang Berkeadilan dan Bermartabat, PT. RajaGrafindo Persada, Jakarta, cet.4. 2016, Hal.138 
berdasarkan konsekuensi-konsekuensi yang diakibatkannya. Konsekuensi yang baik adalah konsekuensi yang memberikan kenikmatan pada seseorang. Dilain pihak, konsekuensi yang buruh adalah konsekuensi yang memberikan penderitaan kepada seseorang. Dengan demikian dalam siatusi apapun pedoman tindakan benar adalah arah memaksimumkan kenikmatan dibandingkan penderitaan, atau dengan kata lain meminimumkan penderitaan dibandingkan kenikmatan. ${ }^{13}$

Bentham terinspirasi oleh kebangkitan humanisme zaman itu yang mengagungkan nilai instrinsik martabat kemanusiaan setiap individu-personal. Nilai humanisme tampak menjadi spirit dasar yang melekat erat dalam pemikiran hukum Bentham. Sebagai pendukung teori kegunaan (utility theory), Bentham mengatakan bahwa tujuan hukum harus berguna bagi individu masyakat demi mencapai kebahagiaan sebesar-besarnya. Bentham dianggap sebagai bapak hukum Inggris karena pemikiran-pemikiran teoretisnya yang dinilai mendukung hukum yang berlaku di Inggris yakni common law ${ }^{14}$.

\section{HASIL DAN PEMBAHASAN}

Kedudukan dan Peran Pemerintah Kota Medan dalam menanggulangi

13 Ahmad Asnawi, Sejarah Para Filsuf Dunia(90 Pemikir Terhebat Yang Berpengaruh Didunia), Indoliterasi, Yogyakarta, 2014, hal. 134

14 Frederikus Fios, Keadilan Hukum Jeremy Bentham Dan Relevansinya Bagi Praktik Hukum Kontemporer, Jurnal Humaniora Vol.3 No.1 April 2012, Hal.302 permasalahan kesejahteraan sosial dan kemiskinan masyarakat Kota Medan

Di Menurut pendapat Bernard Arief Sidharta, Negara Indonesia yang diperjuangkan untuk diwujudkan adalah negara Pancasila dengan ciri-ciri berikut ${ }^{15}$ :

a) Pertama-tama, negara Pancasila adalah negara hukum yang didalamnya penggunaan kekuasaannya harus selalu ada landasan hukumnya dan dalam kerangka batas-batas yang ditetapkan oleh hukum, a fortiori untuk penggunaan kekuasaan publik. Jadi, pemerintahan yang dikehendaki adalah pemerintahan berdasarkan, dengan dan oleh hukum (rule by law dan rule of law).

b) Negara pancasila adalah negara demokrasi yang dalam keseluruhan kegiatan menaranya selalu terbuka bagi partisipasi seluruh rakyat, yang dalam pelaksanaan kewenangan dan penggunaan kekuasaaan publik harus dipertanggungjawabkan kepada rakyat dan harus selalu terbuka bagi pengkajian rasional oleh semua pihak dalam kerangka tata nilai dan tatanan hukum yang berlaku.

c) Negara pancasila adala organisasi seluruh rakyat yang menata diri secara nasional untuk dalam kebersamaan beriktiar, dalam kerangka dan melalui tatanan kaidah hukum yang berlaku, mewujudkan kesejahteraan lahir batin bagi seluruh rakyat dengan selalu mengacu pada nilai-nilai martabat manusia dan

15 Bernard Arief Sidharta, Refleksi Tentang Struktur Ilmu Hukum, CV.Mandar Maju, Bandung, cet.3, 2009, hal.48-49 
Mhd. Yusrizal Adi Syaputra, Kajian Hukum Pemberlakuan Perda Kota Medan Nomor 6 Tahun 2003 Perspektif Utilities Theory

Ketuhanan Yang Maha Esa. Dalam konsepsi negara pancasila ini, maka negara dan pemerintah lebih merupakan koodinasi berbagai pusat pengambilan keputusan rasional yang berintikan asas rasionalitas-efisiensi, asas rasionalitas-kewajaran, asas rasionalitas-berkaidah dan asas rasionalitas-nilai, ketimbang organisasi kekuasaan semata-mata. Dengan demikian, dapat dikatakan bahwa negara Pancasila yang dicitacitakan adalah negara hukum yang berdasarkan asas kerakyatan bertujuan untuk mewujudkan kesejahteraan berkeadilan (keadilan sosial) bagi seluruh rakyat Indonesia serta perdamaian dunia.

Namun, jika perhatian kita disorotkan pada kenyataan faktual masa kini, setelah menjalani 50 tahun kemerdekaan berbangsa dan bernegara, maka akan masih tampak cukup jelas bahwa antara cita-cita negara hukum pancasila dan kenyataan faktual terdapat perbedaan yang cukup lebar. Kualitas dan kuantitas berbagai perangkat aturan hukum positif dengan implementasi dan penegakannya, serta pemerataan kesejahteraan, masih menimbulkan perasaan tidak puas dan keluhan dikalangan masyarkat yang cukup meluas ${ }^{16}$. Kesenjangan antara cita-cita (das sollen) dan kenyataan faktal (das sein) yang cukup lebar terjadi dalam kehidupan sosial masyarakat Indonesia.

Undang-Undang Dasar Negara Republik Indonesia tahun 1945 adalah konstitusi yang berjiwa pancasila.

16 Ibid. Hal. 49
Pancasila adalah jiwa atau rohnya, sedangkan UUD NRI Tahun 1945 adalah wujud atau jasadnya. ${ }^{17}$ UUD NRI Tahun 1945 harus dipahami dalam kaitannya dengan nilai-nilai dasar yang terdapat dalam rumusan pembukaan UUD NRI Tahun 1945 mulai dari alenia I sampai dengan alenia IV, terutama dilihat dalam kaitannya dengan lima nilai dasar yang telah diterima dan disepakati sebagai dasar negara yaitu pancasila. Kelima nilai dasar itu adalah:

1. Ketuhanan Yang Maha Esa

2. Kemanusiaan Yang Adil dan Beradab

3. Persatuan Indonesia

4. Kerakyatan Yang Dipimpin Oleh Hikmat Kebijaksanaan Dalam Permusyawaratan/Perwakilan

5. Keadilan Sosial Bagi Seluruh Rakyat Indonesia

Dengan demikian, dapat dikatakan bahwa UUD NRI Tahun 1945 adalah (1) Konstitusi Berketuhanan, (2) Konstitusi Kemanusiaan, (3) Konstitusi Persatuan, (4) Konstitusi Kerakyatan, (5) Konstitusi Keadilan Sosial. 18

Dalam konteks UUD NRI Tahun 1945 sebagai Konstitusi Keadilan sosial bagi seluruh rakyat Indonesia. Keadilan sosial ini merupakan roh pamungkas dalam UUD NRI Tahun 1945 yang dalam praktik seringkali diabaikan dan dilupakan orang. Perwujudan paling nyata dari nilainilai luhur pancasila dalam rangka citacita hidup bersama segenap bangsa Indonesia dalam kehidupan bermasyarakat dan berbangsa dalam wadah negara Kesatuan Republik

17 Jimly Asshiddiqie, Gagasan Konstitusi Sosial, LP3S, Jakarta, 2015, hal.85

18 Ibid. Hal.85 
Indonesia yang berlandaskan Pancasila dan UUD 1945 adalah struktur kehidupan yang berkeadilan sosial bagi seluruh rakyat Indonesia. ${ }^{19}$

Konsekuensi bahwa UUD 1945 merupakan konstitusi berkeadilan sosial, maka semua norma yang tercermin dalam berbagai kebijakan dan peraturan perundang-undangan serta dokumendokumen kebijakan tertulis lainnya, dan semua tindakan-tindakan pemerintahan yang tercermin dalam program-program pembangunan disertai anggaran pendapatan dan berbelanja negara dan daerah masing-masing, hendaklah diorientasikan untuk meningkatkan kualitas keadilan sosial bagi seluruh rakyat Indonesia. ${ }^{20}$

Menurut Asmara Hadi, menyatakan bahwa Keadilan Sosial itu adalah keadilan yang berlaku dalam hubungan antara manusia dalam masyarakat. Selajutnya menurut Darji Darmodiharjo, keadilan sosial yang termuat dalam sila ke lima Pancasila memiliki makna bahwa ${ }^{21}$ :

(1) Perlakuan yang adil disegala bidang kehidupan, terutama di bidang politik, ekonomi dan sosial budaya

(2) Perwujudan keadilan sosial itu meliputi seluruh rakyat Indonesia

(3) Keseimbangan antara hak dan kewajiban

(4) Menghormati hak milik orang lain

(5) Cita-cita masyarakat yang adil dan makmur yang merata materiel dan

19 Ibid. Hal. 86.

${ }^{20}$ Ibid. Hal. 89

21 Asmara Hadi dan Darji Darmodiharjo dalam Bachsan Mustapa, Sistem Hukum Indonesia Terpadu, PT. Citra Aditya Bakti, Bandung, 2003, hal.21-22 spirituil bagi seluruh rakyat Indonesia.

(6) Cinta akan kemajuan dan pembangunan

Implementasi keadilan sosial sebagaimana yang menjadi tujuan dari pembangunan negara Republik Indonesia merupakan tanggungjawab pemerintah baik pemerintah pusat maupun pemerintah daerah. Khusus kepada pemerintah daerah yang memiliki kedudukan sebagai pemerintahan didaerah yang secara otonom melaksanakan tugas-tugas pemerintahan didaerah.

Otonomi daerah merupakan perwujudan dari sistem desentralisasi yang membagi wewenang dari pemerintah pusat ke daerah, atau otonomi daerah dapat diartikan sebagai pelaksanaan pemerintahan yang desentralistik ${ }^{22}$.

Di dalam Pasal 6 Undang-Undang Nomor 23 tahun 2014 menyatakan bahwa Otonomi Daerah adalah hak, wewenang, dan kewajiban daerah otonom untuk mengatur dan mengurus sendiri urusan pemerintahan dan kepentingan masyarakat setempat dalam sistem Negara Kesatuan Republik Indonesia.

Dalam penyelenggaraan pemerintahan daerah, pemerintah daerah tidak menjalankan pemerintahan seorang diri bersama wakilnya, akan tetapi terdapat perangkat daerah yang menjadi satu paket dalam pemerintahan daerah. Berdasarkan ketentuan Pasal 209 UndangUndang Nomor 23 tahun 2014, perangkat daerah dibagi menjadi dua yaitu perangkat

22 Yusnani Hasyimzoem dkk, Hukum Pemerintahan Daerah, Rajawali Press, Jakarta, 2017, hal.97 
Mhd. Yusrizal Adi Syaputra, Kajian Hukum Pemberlakuan Perda Kota Medan Nomor 6 Tahun 2003 Perspektif Utilities Theory

daerah provinsi dan perangkat daerah kabupaten/kota.

Perangkat daerah provinsi terdiri dari:
a) Sekretaris daerah
b) Sekretaris DPRD
c) Inspektorat,
d) Dinas
e) Badan

Sedangkan Perangkat Daerah Kabupaten/Kota terdiri dari:
a) Sekretaris Daerah
b) Sekretaris DPRD
c) Inspektorat
d) Dinas
e) Badan
f) Kecamatan

Sebagaimana yang diatur dala Undang-Undang Nomor 23 tahun 2014, bahwa pemerintahan daerah dipimpin oleh kepala daerah, dimana tugas dari kepala daerah seperti yang diatur dalam Pasal 65 yakni:

(a) Memimpin pelaksanaan urusan pemerintahan yang menjadi kewenangan daerah berdasarkan ketentuan peraturan perundangundangan dan kebijakan yang diterapkan bersama DPRD;

(b) Memelihara ketentraman dan ketertiban masyarakat

(c) Menyusun dan mengajukan rancangan Peraturan Daerah tentang RPJD dan rancangan Perda tentang RPJMD kepada DPRD untuk dibahas bersama DPRD serta menyusun dan menetapkan RKPD

(d) Menyusun dan mengajukan rancangan PERDA tentang APBD, Rancangan PERDA tentang perubahan APBD, dan rancangan PERDA tentang pertanggungjawaban pelaksanaan APBD kepada DPRD untuk dibahasa bersama

(e) Mewakili daerahnya di dalam dan diluar pengadilan, dan dapat menunjuk kuasa hukum untuk mewakilinya sesuai dengan ketentuan peraturan perundangundangan

(f) Mengusulkan pengangkatan wakil kepala daerah

(g) Melaksanakan tugas lain sesuai dengan ketentuan peraturan perundang-undangan

Dalam melaksanakan tugas-tugas yang telah ditentukan oleh undangundang, kepala daerah memiiki wewenang yaitu:

(1) Mengajukan rancangan PERDA

(2) Menetapkan PERDA yang telah mendapat persetujan bersama DPRD

(3) Menetapkan PERKADA dan Keputusan Kepala Daerah

(4) Mengambil tindakan tertentu dalam keadaan mendesak yang sangat dibutuhkan oleh daerah dan/atau masyarakat

(5) Melaksanakan wewenang lain sesuai dengan ketentuan peraturan perundang-undangan

Otonomi daerah membuka kesempatan yang seluas-luasnya bagi daerah untuk mengoptimalkan segala potensi terbaiknya, karena setiap daerah pasti memiliki satu atau beberapa keunggulan tertentu. Salah satu cara yang dapat dilakukan oleh pemerintah daerah di era otonomi daerah adalah dengan cara mamaksimalkan peran serta masyarakat dan melaksanakan pemberdayaan masyarakat. Menurut Sumodoningrat menyatakan bahwa dalam dunia bisnis, pemberdayaan 
merupakan upaya pemberian kesempatan dan atau memfasilitasi kelompok miskin agar mereka memiliki modal, teknologi, informasi, jaminan pemasaran,dll. Mengacu pada hal tersebut dalam menentukan arah pembangunan dan secara praktis menunjuk pada upaya-upaya memberdayakan sektor Usaha, Mikro, Kecil dan Menengah (UMKM) yang notabene pelakunya mayoritas adalah rakyat yang kurang dalam pengaksesan permodalan dan pengusaan pasar $^{23}$.

Desentralisasi pemerintahan melalui pemberian otonomi kepada daerah untuk melaksanakan pemerintahan sendiri adalah sebuah konsep yang dipakai oleh hampir 60 negara sebagai salah satu strategi pembangunan. Selain dipandang positif dari sisi efektivitas manajemen pemerintahan, pelaksanaan otonomi juga dipandang sesuai dengan prinsip-prinsip demokrasi yang memungkinkan setiap warga negara untuk menentukan sendiri nasib dan mengapresiasikan keinginannnya secara bebas. ${ }^{24}$ Salah satu alasan dilaksanakannya otonomi daerah adalah untuk memperbaiki kinerja penyelenggaraan pemerintahan sesuai

23 Robby Firmansyah dkk, Strategi Pemerintah Daerah Dalam Pemberdayaan Usaha Mikro, Kecil Dan Menengah Di Kabupaten Madiun (Studi pada Dinas Koperasi, Perindustrian, Perdagangan dan Pariwisata Kabupaten Madiun dan Sentra Industri Brem Desa Kaliabu Kecamatan Mejayan Kabupaten Madiun, Jurnal Administrasi Publik (JAP), Vol. 2, No. 1, Hal. 154-155

24 Lindaman dan Thurmaier dalam Budi Setiyono, Birokrasi Dalam Prespektif Politik dan Administrasi, Nuansa Publishing, Bandung, Cet.II.2016, Hal.181 dengan aspirasi masyarakat, bukan untuk mentransfer masalah-masalah kebobrokan pemerintahan di daerah baik yang berada di lembaga legislatif (DPRD) maupun Eksekutif (Kepala Daerah) dan juga birokrasi daerah, memiliki peranan yang sangat menentukan untuk merealisasikan idealisme pemerintahan yang baik. ${ }^{25}$ Pelaksanaan otonomi daerah, setiap Kabupaten/Kota memiliki kewenangan penuh untuk memformulasikan kebijakan, visi, misi, dan program pembangunan yang mendekati kebutuhan dan keinginan dari daerah masing-masing.

Otonomi daerah akan memberikan kesempatan pada daerah untuk memanfaatkan dan mengembangkan potensi otonomi daerahnya secara lebih leluasa untuk kepentingan daerahnya sendiri secara proposional. Daerah dapat mengelola dan mengeksploitasi sumber daya alam yang tersedia, mengembangkan sentra perekonomian, mengembangkan sistem perekonomian daerah yang spesifik, dan mengatur tata pemungutan retribusi dan pajak daerah secara lebih lelausa. Otonomi daerah dapat memberikan kesempatan pada daerah untuk memanfaatkan hasil kekayaan alam yang ada didaerahnya untuk kepentingan penduduk lokal, sehingga daerah tidak hanya mendapatkan limbah kegiatan eksploitasi sumber daya alam. ${ }^{26}$

Di dalam hal peningkatan kesejahteraan sosial masyarakat didaerah, pemerintah daerah memiliki kedudukan sebagai pembuat kebijakan. Sebagai pembentuk kebijakan ( policy maker)

\footnotetext{
25 Ibid. Hal.182

${ }^{26}$ Ibid. Hal. 186
} 
maka, Pemerintah Daerah memiliki peran strategis untuk mendatangkan manfaat dan perlindungan kepada masyarakat yang termarjinalkan baik secara ekonomi, politik maupun sosial.

Kota Medan, sebagai salah satu daerah metropolitan di Indonesia tidak terhindarkan ditengah masyarakat yang semakin maju, modern ternyata banyak juga ditemukan masyarakat ataupun kelompok-kelompok orang yang terpinggirkan dan menjadi kelompok masyarakat yang termarjinalkan, seperti kelompok masyarakat miskin kota, gelandangan/pengemis. Dan pada satu titik, persoalan terhadap realitas sosial tersebut menjadi kontras terhadap visi dan misi pemerintah daerah Kota Medan.

Pada prinsipnya, implementasi dari otonomi daerah diharapkan dapat memberikan pelayanan terbaik bagi masyarakat, mengakomodasi seluruh kepentingan masyarakat tanpa diskriminasi, pengurangan beban hidup masyarakat terutama dalam bidang ekonomi serta peningkatan kejahteraan sosial masyarakat secara keseluruhan. Oleh karena itu, pemerintah Kota Medan sudah selayaknya menjalankan perannya sebagai pemerintah yang melaksanakan fungsi pemerintahan di daerah dengan tepat sasaran.

Keberhasilan suatu daerah dalam menjalankan otonomi daerahnya ditentukan oleh kebijakan-kebijakan dari daerah itu sendiri, olehkarena itu, jika melihat pada kebijakan pemerintah daerah Kota Medan saat ini, tidak seluruhnya memberikan dampak secara menyeluruh pada semua lapisan masyarakat.
Pembangunan daerah harus dipahami sebagai suatu proses yang multidimensial yang melibatkan seluruh aspek, rekonstruksi seluruh sub sistem yang menjadi pilar terlaksanannya otonomi daerah, diantara pilar sistem otonomi daerah tersebut yakni:
a) Hukum
b) Ekonomi
c) Sosial
d) Politik
e) Budaya
f) Agraria
g) Administrasi
h) Partisipasi masyarakat
i) Stakeholders
j) Dukungan pemerintah pusat
k) Sumber daya alam dan lingkungan

Dari sub sistem pendukung terlaksanannya prinsip otonomi dalam pemerintahan di Kota Medan, diharapkan berjalan secara konsisten, koheren, continiue, mengedepankan kepastian, dan keadilan serta kemanfaatan dalam setiap tindakan dari pemerintah Kota Medan.

Keterlibatan publik dalam pengambilan keputusan atau kebijakan pada realitasnya sudah diwakilkan melalui lembaga perwakilan rakyat didaarah, hanya saja persoalannya anggota legislatif didaerah (DPRD) belum memaksimalkan dan mengoptimalisasi fungsi yang dimiliki DPRD Kota Medan sebagai mitra pemerintah Kota Medan dalam pembentukan regulasi daerah maupun sebagai pengawas setiap tindakan dan pengambilan keputusan pemerintah daerah di Kota Medan.

Pemko Medan memiliki peran stategis dalam rangka mengatasi permasalahan sosial ditengah masyarakat Kota Medan, peran tersebut dapat berupa: 
(1) Pemko Sebagai Executor, dalam hal ini pemerintah Kota Medan sebagai pelaksana langsung pengentasan permasalahan sosial secara langsung pada masyarakat Kota Medan. Pemerintah Kota Medan memiliki kepasitas dan kewenangan untuk membentuk regulasi daerah dan kebijakan-kebijakan daerah terkait penanggulangan permasalahan sosial masyarakat kota Medan

(2) Pemko Medan sebagai fasilitator. Dalam hal ini, pemko Medan menjadi fasilitator dalam menangani permasalahan sosial seperti pengemis, dengan menjalankan program dari pemerintah pusat melalui kementrian sosial, tenaga kerja, kementrian ekonomi maupun program kerja pengentasan kemiskinan dari pemerintah provinsi sumatera utara. Hal tersebut dapat berjalan dengan baik apabila komunikasi antara Pemko dengan Pemprov SUMUT dan Pemerintah Pusat sudah terbangun dengan baik.

Diharapkan dengan mengedepankan dua peran Pemko Medan dalam upaya mengatasi permasalahan sosial, maka akan terlaksana sistem penanggulangan kesejahteraan sosial dengan baik tanpa harus mengeluarkan regulasi yang tidak bermanfaat dan justru memberikan reaksi yang diskminitatif pada sebagian masyarakat.

Keberadaan Peraturan Daerah Kota Medan Nomor Nomor 6 Tahun 2003 Tentang Larangan Gelandangan Dan Pengemisan Serta Praktek Susila memberikan jaminan Kesejahteraan sosial masyarakat Kota Medan dalam prespektif Utilities Theory

Pasal 1 ayat (3) UUD 1945 menegaskan bahwa Indonesia adalah negara hukum, hal ini berarti bahwa dalam penyelenggaraan kehidupan berbangsa, bermasyarakat, dan bernegara harus didasarkan pada hukum (konstitusi) maupun peraturan perundang-undangan lainnya baik secara hierarki maupun secara non formal ( norma tidak tertulis) yang berlaku dimasyarakat.

Berdasarkan Pasal 10 UndangUndang Nomor 12 tahun 2011, hierarki peratura perundang-undangan di Indonesia terdiri atas:

a. UUD 1945

b. Ketetapan MPR RI

c. Undang-Undang/Perpu

d. Peraturan Pemerintah (PP)

e. Peraturan presiden

f. Peraturan derah provinsi

g. Peraturan daerah kabupaten/kota

Peraturan daerah merupakan salah satu instrumen bagi pemerintah daerah dalam melaksanakan tugas dan wewenangnya berdasarkan sistem ekonomi daerah yang memberikan wewenang untuk mengurus dan mengatur segala urusan rumah tangganya sendiri termasuk membentuk peraturan daerah. Sesuai dengan ketentuan dalam Pasal 18 Ayat (6) UUD 1945 menyebutkan bahwa Pemerintah daerah berhak menetapkan peraturan daerah dan peraturanperaturan lain untuk melaksanakan otonomi dan tugas pembantuan. Berdasarkan ketentuan tersebut, maka peraturan daerah merupakan salah satu elemen pendukung terlaksananya otonomi daerah. 
Mhd. Yusrizal Adi Syaputra, Kajian Hukum Pemberlakuan Perda Kota Medan Nomor 6 Tahun 2003 Perspektif Utilities Theory

Berdasarkan ketentuan Pasal 1 angka 25 Undang-Undang Nomor 23 tahun 2014 menegaskan bahwa peraturan daerah adalah peraturan daerah provinsi dan peraturan daerah kabupaten/kota. Selanjutnya didalam Pasal 263 ayat (1) Undang-Undang Nomor 23 tahun 2014 dikatakan bahwa peraturan daerah dibentuk untuk menyelenggarakan otonomi daerah dan tugas pembantuan, daerah membentuk peraturan daerah. Didalam ayat (2) disebutkan bahwa peraturan daerah dibentuk oleh DPRD dengan persetujuan bersama kepala daerah. Didalam ayat (3) peraturan daerah memuat materi muatan yaitu:

(a) Penyelenggaraan otonomi daerah dan tugas pembantuan

(b) Penjabaran lebih lanjut ketentuan peraturan perundang-undangan yang lebih tinggi

Peraturan Daerah Kota Medan Nomor Nomor 6 Tahun 2003 Tentang Larangan Gelandangan Dan Pengemisan Serta Praktek Susila merupakan salah satu peraturan daerah Kota Medan yang memiliki pengaruh dan akibat langsung terhadap kepentingan masyarakat khususnya masyarakat yang termarjinalkan secara ekonomi dan kelas sosial di masyarakat.

Dibentuknya peraturan daerah Kota Medan Nomor 6 tahun 2003 merupakan salah satu upaya pemerintah kota medan dalam mewujudkan Kota Medan yang Bestari, pelaksanaan penanggulangan gelandangan dan pengemis serta praktek tuna susila secara terpadu di Kota Medan. Pemko Medan berpendapat Bahwa dengan semakin meningkatnya dan perkembangan jumlah gelandangan dan pengemis serta praktek tuna susila, yang melakukan kegiatan pengemisan di medan-medan jalan, traffic light, pelataran masjid-masjid dan jembatanjembatan penyebrangan serta kegiatan tuna susila ditempat-tempat umum, taman-taman, pinggiran sungai, bawah jembatan, hotel, losmen, dan tempat lainnya di kota medan ${ }^{27}$. Pemerintah Kota Medan beranggapan bahwa kegiatan yang dilakukan dengan berbagai cara, untuk menimbulkan belas kasihan orang lain, ini merupakan penyakit mental atau pemalas yang tidak sejalan dengan ajaran agama, sedangkan tuna susila merupakan tindakan yang bertentangan dengan norma-norma sosial dan keagamaan dan sangat membahayakan kehidupan generasi muda serta dapat menyebabkan penyebaran virus AIDS / HIV dan virus penyakit lainnya yang semakin meluas.

Di dalam konteks sosial dapatlah dikatakan bahwa gelandangan, pengemis dan tuna susila merupakan tindakan yang termasuk penyakit mental atau pemalas. Akan tetapi dimata hukum, keberadaan masyarakat yang menjadi gelandangan, pengemis dan tuna susila sama kedudukannya, baik hak dan kewajiban hukumnya. Oleh karena itu, keberadaan gelandangan, pengemis dan tuna susila di Kota Medan tidak lah dapat dikatakan semata-mata sebagai penyakit mental semata, tetapi lebih arif jika dikatakan bahwa kelompok masyarakat yang menjadi gelandangan, pengemis maupun tuna susila tersebut merupakan akibat

\footnotetext{
27 Lihat Konsideran menimbang Peraturan Daerah Kota Medan Nomor 6 tahun 2003
} 
perkembangan sosial ekonomi serta politik ditengah masyarakat.

Upaya untuk mengatasi keberadaan kelompok masyarakat gelandangan, pengemis dan tuna susila tidak lah cukup hanya dengan membuat norma dalam bentuk peraturan daerah sebagai sebuah norma yang melarang keberadaan kelompok masyarakat tersebut. Keberadaan kelompok masyarakat tersebut secara konstitusional diatur dalam konstitusi Indonesia, Pasal 27 ayat (1) dan (2) UUD 1945

(1) Segala warga negara bersamaan kedudukannya di dalam hukum dan pemerintahan dan wajib menjunjung tinggi pemerintahan itu dengan tidak ada kecualinya

(2) Tiap-tiap warga negara negara berhak atas pekerjaan da penghidupan yang layak bagi kemanusiaan

\section{Pasal 28A UUD 1945}

Setiap orang berhak untuk hidup serta berhak mempertahankan hidup dan kehidupannya

Pasal 28 C ayat (2) UUD 1945 "Setiap orang berhak untuk memajukan dirinya dalam memperjuangkan haknya secara kolektif untuk membangun masyarakat, bangsa dan negaranya"

\section{Pasal 28D UUD 1945}

(1) Setiap orang berhak atas pengakuan, jaminan, perlindungan, dan kepastian hukum yang adil serta perlakuan yang sama dihadapan hukum

Pasal 28H UUD 1945
(1) Setiap orang berhak hidup sejahtera lahir dan batin, bertempat tinggal, dan mendapatkan lingkungan yang baik dan sehat serta berhak memperoleh pelayanan kesehatan.

(2) Setiap orang berhak mendapat kemudahan dan perlakuan khusus untuk memperoleh kesempatan dan manfaat yang sama guna mencapai persamaan dan keadilan

(3) Setiap orang berhak atas jaminan sosial yang memungkinkan pengembangan dirinya secara utuh sebagai manusia yang bermartabat

\section{Pasal 28 I UUD 1945}

(1) Hak untuk hidup, hak untuk tidak disiksa, hak kemerdekaan pikiran dan hati nurani, hak beragama, hak untuk tidak diperbudak, hak untuk diakui sebagai peribadi dihadapa hukum dan hak untuk tidak dituntut atas dasar hukum yang berlaku surut adalah hak asasi manusia yang tidak dapat dikurangi dalam keadaan apapun

(2) Setiap orang berhak bebas dari perlakuan diskriminatif atas dasar apa pun dan berhak mendapatkan perlindungan terhadap perlakuan yang bersifat diskriminatif itu

\section{Pasal 34 UUD 1945}

(1) Fakir miskin, dan anak-anak yang terlantar dipelihara oleh negara

(2) Negara mengembangkan sistem jaminan sosial bagi seluruh rakyat dan memberdayakan masyarakat yang lemah dan tidak mampu sesuai dengan martabat kemanusiaan 
Mhd. Yusrizal Adi Syaputra, Kajian Hukum Pemberlakuan Perda Kota Medan Nomor 6 Tahun 2003 Perspektif Utilities Theory

(3) Negara bertanggungjawab atas penyediaan fasilitas pelayanan kesehatan dan fasilitas pelayanan umum yang baik

Berdasarkan beberapa ketentuan didalam UUD 1945, jika dilihat pada Peraturan Daerah Nomor 6 Tahun 2003, Didalam Pasal 1 huruf f, g, dan h Perda Nomor 6 tahun 2003 disebutkan pengertian :

f. Gelandangan adalah orang-orang yang hidup dalam keadaan tidak sesuai dengan norma kehidupan yang layak dalam masyarakat setempat serta tidak mempunyai tempat tinggal dan pekerjaan yang tetap di wilayah tertentu dan hidup mengembara ditempat-tempat umum.

g. Pengemis adalah orang-orang yang mendapatkan penghasilan dengan meminta-minta dimuka umum dengan berbagai cara baik berupa mengamen dan alasan lainnya untuk mengharapkan belas kasihan dari orang lain.

h. Tuna susila adalah seseorang yang melakukan hubungan kelamin tanpa ikatan perkawinan yang sah dengan mendapatkan imbalan jasa financial maupun materil bagidirinya maupun pihak lain dan perbuatan tersebut bertentangan dengan norma sosial, agama dan kesusilaan (termasuk didalamnya wanita tuna susila, mucikari, gigolo, dan waria tuna susila)

Berdasarkan pengertian diatas, dapatlah dikatakan bahwa pemerintah Kota medan ada mendiskrimininasikan keberadaan gelandangan, pengemis dan tuna susila sebagai penyakit masyarakat. Dan selanjutnya Perda Nomor 6 tahun
2003 memberikan batasan didalam Pasal 2 bahwa

(1) Dilarang melakukan penggelandangan dan pengemisan berkelompok atau perorangan atau dengan cara apapun dengan mempengaruhi/menimbulkan belas kasihan orang lain

(2) Dilarang dengan sengaja memperajat orang lain seperti bayi, anak kecil dan atau mendatangkan seseorang/beberapa orang untuk maksud melakukan pengemisan

(3) Dilarang membujuk atau memikat orang lain dengan dengan perkataan-perkataan dan isyarat dan atau dengan perbuatan lainnya dengan maksud mengajak melakukan perbuatan pelacuran dijalan umum dan atau tempat yang diketahui/dikunjungi oleh orang lain baik perorangan atau beberapa orang.

(4) Dilarang dengan sengaja memanggil/mendatangkan seseorang, beberapa orang untuk maksud melakukan perbuatanperbuatan pelacuran / tuna susila

(5) Barang siapa mengetahui, melihat, melanggar, ada perbuatan sebagaimana dimaksud ayat (1), (2), (3), dan (4) pasal ini berkewajiban melaporkan kepada pihak yang berwenang.

Berdasarkan ketentuan Pasal 2 didalam Perda Nomor 6 tahun 2003, pembuat Perda beranggapan bahwa pelanggaran Pasal 2 tersebut dapat dikenakan sanksi pidana dengan ancaman 
pelanggaran. Hal tersebut ditegaskan didalam Pasal 5.

(1) Barang siapa yang melanggar ketentuan pasal 2 peraturan daerah ini diancam pidana kurungan paling lama 6 (enam) bulan dan atau denda sebanyakbanyaknya Rp. 5.000.000,- (lima juta rupiah)

(2) Tindak pidana sebagaimana dimaksud ayat (1) adalah pelanggaran.

Semangat untuk memperjuangkan Kota Medan yang BESTARI oleh Pemko Medan dan DPRD Kota Medan melalui Perda Nomor 6 tahun 2003 terlihat sangat jelas, hanya saja, keberadaan Peraturan daerah tersebut tidak berimbang menempatkan hak dan kewajiban masyarakat yang dikatakan sebagai pengemis, gelandangan dan tuna susila tersebut sebagai bagian dari Warga Negara Indonesia, sekaligus melindungi hak-hak asasi sebagai manusia yang dilindungi hak dan kewajibannya didalam undang-undang dasar.

Realitas sosial tidak dipungkiri bahwa keberadaan pengemis, gelandangan dan tuna susila merusak pemandangan mata dalam perspektif sosiologis, tetapi tidak lah pula kemudian, keberadaan masyarakat yang termarjinal kan tersebut menjadi sebuah tindakan kriminal atau lebih tepatnya dikriminalisasikan. Hal ini bertentangan dengan ketentuan dalam UUD 1945 khususnya Pasal Pasal 27 ayat (1) dan (2), Pasal 28A, Pasal 28H, Pasal 28 I, Pasal 34 UUD 1945.

Lebih arif dan bijaksanana jika pemerintah mengakomodir keberadaan para kelompok masyarakat gelandanga, pengemis dan tuna susila untuk kemudian dilakukan pembinaan dan juga dilakukan pemberdayaan terhadap kelompok masyarakat tersebut. Karena pada prinsipnya, kelompok masyarakat yang terjebak dalam kelompok-kelompok seperti itu bukanlah semata-mata karena keinginan pribadi dirinya tetapi lebih dipengaruhi oleh faktor diluar dirinya seperti keadaan ekonomi, sosial lingkungan.

Peraturan daerah Nomor 6 tahun 2003 hingga saat ini, dinilai kurang bermanfaat, karena pada kenyataannya, peraturan daerah tersebut tidak dapat menyelesaikan permasalahan kelompok marjinal tersebut. Hal ini dibuktikan dengan, hingga saat ini masih banyak dijumpai kelompok-kelompok gelandangan, pengemis dan tuna susila di Kota Medan. Perkembangan jaman dan teknonologi telah membawa perubahan signifikan khususnya terhadap perilaku tuna susila di Kota Medan yang perlu dilakukan kajian akademik yang komprehensif untuk melihat eksistensi kelompok tersebut ditengah masyarakat.

Revitalisasi keberadaan badanbadan pemerintah Kota Medan, seperti dinas sosial, dinas tenaga kerja, bekerjasama dengan pemerintah pusat melalui kementerian agama, kementerian sosial dan kementerian perumahan rakyat harus dilakukan untuk memenuhi dan melindungi hak-hak masyarakat tersebut sehingga untuk kemudian masyarakat tersebut dapat dibina, diberi keterampilan dan keahlian sehingga kedepannya masyarakat yang termarjinalkan tersebut tidak lagi dianggap sebagai perilaku kriminal tetapi sebatas dinamika sosial semata. Yang dalam 
Mhd. Yusrizal Adi Syaputra, Kajian Hukum Pemberlakuan Perda Kota Medan Nomor 6 Tahun 2003

Perspektif Utilities Theory

pendekatannya,tidaklah harus sematamata melalui pendekatan norma hukum yang melarang dan mengkriminalisasi perilaku tersebut, tetapi dilakukan pendekatan dengan perspektif sosiologis masyarkat perkotaaan, dan aspek ekonomi.

\section{SIMPULAN}

Keberadaan Peraturan Daerah Kota Medan Nomor 6 tahun 2003 tentang Larangan Gelandangan Dan Pengemisan Serta Praktek Susila Di Kota Medan, sudah selayaknya ditinjau kembali atau dilakukan revisi terhadap klausul pasalpasal yang terdapat didalamnya dengan melihat lebih komprehensif keberadaan kelompok masyarakat sebagai gelandanga, pengemis dan tunasusila di tengah masyarakat Kota Medan.

Implementasi peraturan daerah Nomor 6 tahun 2003 tersebut tidaklah memberikan output yang signifikan, sehingga tidaklah dikatakan perda Nomor 6 tahun 2003 sudah mengedepankan asas kepastian hukum, keadilan dan kemanfaatan dalam penerapannya, karena keberadaan kelompok masyarakat gelandangan, pengemis dan tunasusila masih ditemukan di Kota Medan, bahkan jumlahnya relatif semakin bertambah.

Dalam perspektif ulities teory, keberadaan Perda Nomor 6 tahun 2003 tidak memberikan manfaat maksimal untuk mewujudkan Kota Medan yang BESTARI dan menjadi Kota Metropolitan. Sehingga perlu dilakukan pengkajian ulang terhadap keberadaan Perda tersebut atau dicabut diganti dengan perda yang baru yang sesuai dengan nilai-nilai pancasila dan ketentuan normatif didalam UUD 1945 sehingga keberdaan peraturan daerah menjadi sebuah regulasi yang memiliki asas kepastian hukum, keadilan dan kemanfaatan.

\section{DAFTAR PUSTAKA}

Ambar Teguh Sulistiyani, Kemitraan dan ModelModel Pemberdayaan, Gava Media, Yogyakarta, 2017

Ahmad Asnawi, Sejarah Para Filsuf Dunia(90 Pemikir Terhebat Yang Berpengaruh Didunia), Indoliterasi, Yogyakarta, 2014.

Asmara Hadi dan Darji Darmodiharjo dalam Bachsan Mustapa, Sistem Hukum Indonesia Terpadu, PT. Citra Aditya Bakti, Bandung, 2003.

Bernard Arief Sidharta, Refleksi Tentang Struktur Ilmu Hukum, CV.Mandar Maju, Bandung, cet.3, 2009.

Frederikus Fios, Keadilan Hukum Jeremy Bentham Dan Relevansinya Bagi Praktik Hukum Kontemporer , Jurnal Humaniora Vol.3 No.1 April 2012.

Jimly Asshiddiqie, Gagasan Konstitusi Sosial, LP3S, Jakarta, 2015.

Lindaman dan Thurmaier dalam Budi Setiyono, Birokrasi Dalam Prespektif Politik dan Administrasi, Nuansa Publishing, Bandung, Cet.II.2016.

Muammil Sun'an dan Abdurrahman Senuh, Ekonomi Pembangunan Daerah, Mitra Wacana Media, Jakarta, 2015

Peter Mahmud Marzuki, Penelitian Hukum, Kencana Prenada Media Group, Jakarta, Cet.5, 2009

Robby Firmansyah dkk, Strategi Pemerintah Daerah Dalam Pemberdayaan Usaha Mikro, Kecil Dan Menengah Di Kabupaten Madiun (Studi pada Dinas Koperasi, Perindustrian, Perdagangan dan Pariwisata Kabupaten Madiun dan Sentra Industri Brem Desa Kaliabu Kecamatan Mejayan Kabupaten Madiun, Jurnal Administrasi Publik (JAP), Vol. 2, No. 1.

Sedarmayanti, Good Governance (Kepemerintahan yang baik) dan Good Corporate Governance ( tata Kelola Perusahaan yang baik), CV. Mandar Madju, Bandung, 2007

Teguh Prasetyo dan Abdul Halim Barkatullah, Filsafat, Teori dan Ilmu Hukum : Pemikian Menuju Masyarakat Yang Berkeadilan dan 
Bermartabat, PT. RajaGrafindo Persada, Jakarta, cet.4. 2016.

Yusnani Hasyimzoem dkk, Hukum Pemerintahan Daerah, Rajawali Press, Jakarta, 2017.

Yusril Ihza Mahendra Perlukah Undang-Undang Tentang Perlindungan Fakir Miskin Dan Anak Terlantar?, Majalah Hukum dan Pembangunan, Nomor 3 Tahun XXV Juni 1995

Undang-Undang Nomor 11 tahun 2009 tentang Kesejahteraan Sosial

Peraturan Daerah Kota Medan Nomor : 6 Tahun 2003 Tentang Larangan Gelandangan Dan Pengemisan Serta Praktek Susila Di Kota Medan. 